Keywords: Sludge, DWPF, CPC

Retention: Permanent

\title{
DWPF Simulant CPC Studies for SB8
}

J.D. Newell

August 2013

Savannah River National Laboratory Savannah River Nuclear Solutions, LLC Aiken, SC 29808

Prepared for the U.S. Department of Energy under contract number DE-AC09-08SR22470. 
SRNL-STI-2012-00620

Revision 0

\section{DISCLAIMER}

This work was prepared under an agreement with and funded by the U.S. Government. Neither the U.S. Government or its employees, nor any of its contractors, subcontractors or their employees, makes any express or implied:

1. warranty or assumes any legal liability for the accuracy, completeness, or for the use or results of such use of any information, product, or process disclosed; or

2. representation that such use or results of such use would not infringe privately owned rights; or

3. endorsement or recommendation of any specifically identified commercial product, process, or service.

Any views and opinions of authors expressed in this work do not necessarily state or reflect those of the United States Government, or its contractors, or subcontractors.

\section{Printed in the United States of America}

Prepared for

U.S. Department of Energy 


\section{REVIEWS AND APPROVALS}

AUTHORS:

J.D. Newell, Process Technology Programs

Date

TECHNICAL REVIEW:

M.E. Stone, Process Technology Programs

Date

D.P. Lambert, Process Technology Programs

Date

APPROVAL:

D.R. Click, Manager

Date

Process Technology Programs

S.L. Marra, Manager

Date

Environmental \& Chemical Process Technology Research Programs

E.J. Freed, Manager

Date

Process Cognizant Engineering, Waste Solidification Engineering 


\section{EXECUTIVE SUMMARY}

Prior to processing a Sludge Batch (SB) in the Defense Waste Processing Facility (DWPF), flowsheet studies using simulants are performed. Typically, the flowsheet studies are conducted based on projected composition(s). The results from the flowsheet testing are used to 1) guide decisions during sludge batch preparation, 2) serve as a preliminary evaluation of potential processing issues, and 3) provide a basis to support the Shielded Cells qualification runs performed at the Savannah River National Laboratory (SRNL). SB8 was initially projected to be a combination of the Tank 40 heel (Sludge Batch 7b), Tank 13, Tank 12, and the Tank 51 heel.

In order to accelerate preparation of SB8, the decision was made to delay the oxalate-rich material from Tank 12 to a future sludge batch. SB8 simulant studies without Tank 12 were reported in a separate report. ${ }^{1}$ The data presented in this report will be useful when processing future sludge batches containing Tank 12 .

The wash endpoint target for SB8 was set at a significantly higher sodium concentration to allow acceptable glass compositions at the targeted waste loading. Four non-coupled tests were conducted using simulant representing Tank 40 at 110-146\% of the Koopman Minimum Acid requirement. Hydrogen was generated during high acid stoichiometry (146\% acid) SRAT testing up to $31 \%$ of the DWPF hydrogen limit. SME hydrogen generation reached $48 \%$ of of the DWPF limit for the high acid run.

Two non-coupled tests were conducted using simulant representing Tank 51 at $110-146 \%$ of the Koopman Minimum Acid requirement. Hydrogen was generated during high acid stoichiometry SRAT testing up to $16 \%$ of the DWPF limit. SME hydrogen generation reached $49 \%$ of the DWPF limit for hydrogen in the SME for the high acid run.

Simulant processing was successful using previously established antifoam addition strategy. Foaming during formic acid addition was not observed in any of the runs.

Nitrite was destroyed in all runs and no $\mathrm{N}_{2} \mathrm{O}$ was detected during SME processing.

Mercury behavior was consistent with that seen in previous SRAT runs. Mercury was stripped below the DWPF limit on $0.8 \mathrm{wt} \%$ for all runs.

Rheology yield stress fell within or below the design basis of 1-5 Pa. The low acid Tank 40 run (106\% acid stoichiometry) had the highest yield stress at $3.78 \mathrm{~Pa}$. 


\section{TABLE OF CONTENTS}

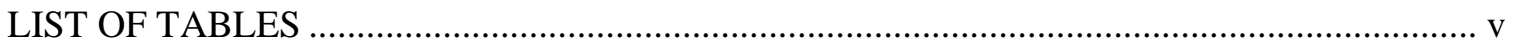

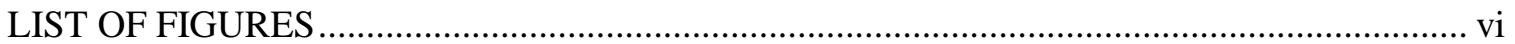

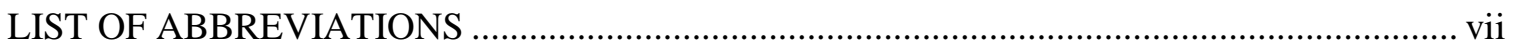

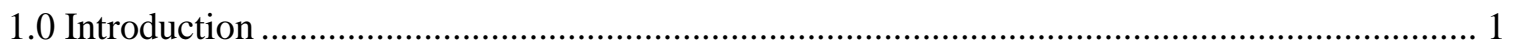

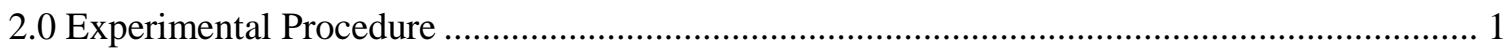

2.1 Process and Sample Analytical Methods ............................................................................ 1

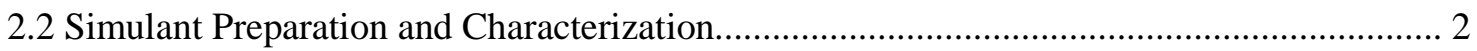

2.3 Chemical Process Cell Simulation Details ............................................................................. 5

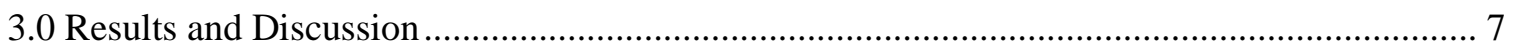

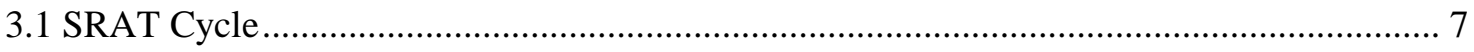

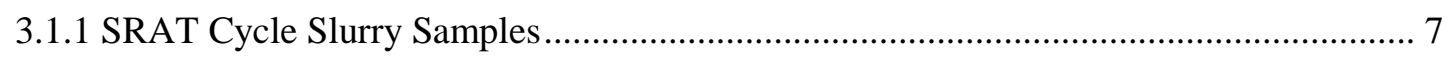

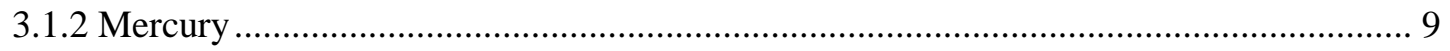

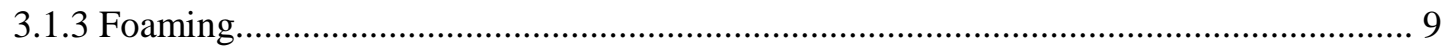

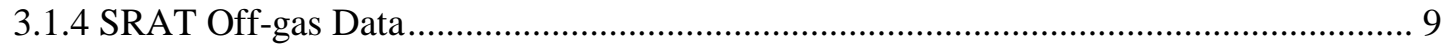

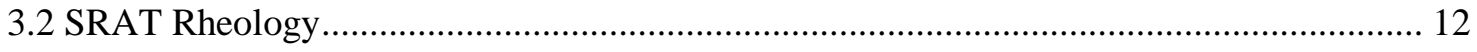

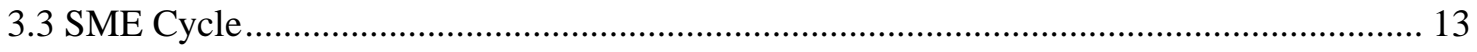

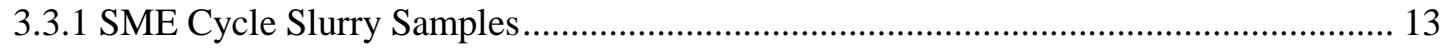

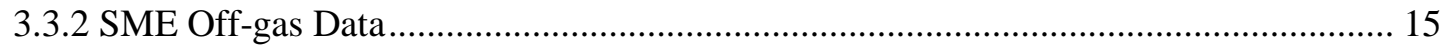

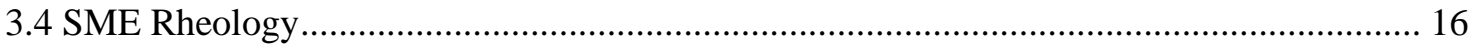

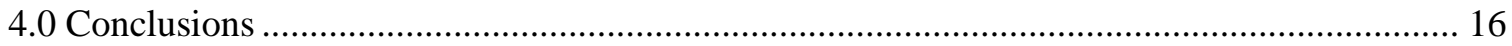

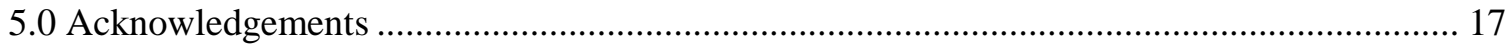

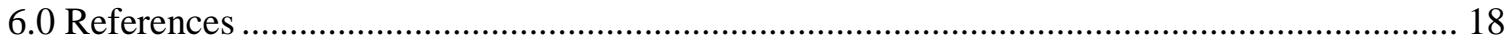

\section{LIST OF TABLES}

Table 1. Elemental composition of SRAT feeds calcined at $1100^{\circ} \mathrm{C}$, wt $\%$.................................. 3

Table 2. Simulant and Radioactive Feed Properties...................................................................... 4

Table 3. Noble metal and mercury, wt $\%$ in total solids ............................................................. 5

Table 4. Stoichiometric acid calculation results, moles acid/L trimmed slurry …......................... 6

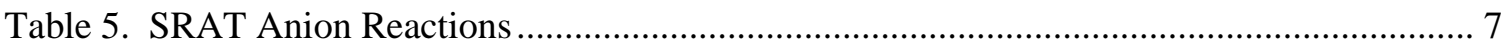

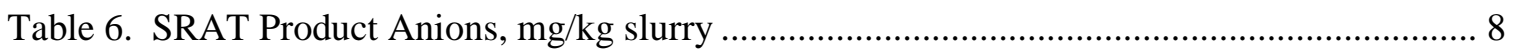

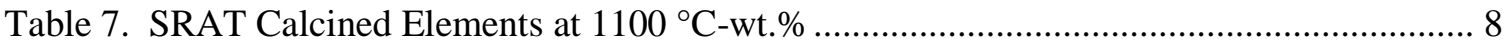




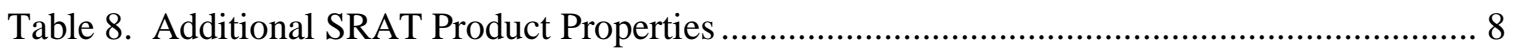

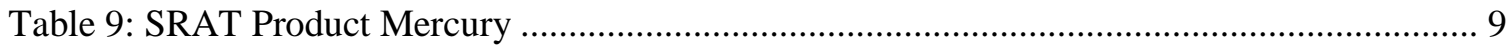

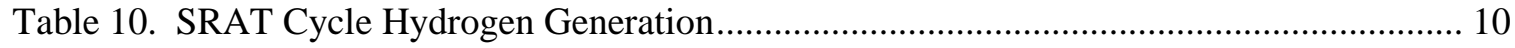

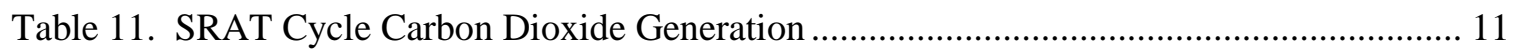

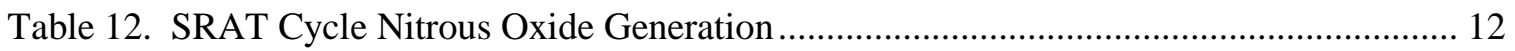

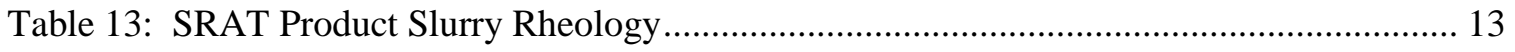

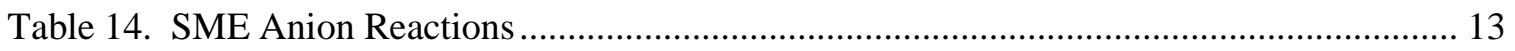

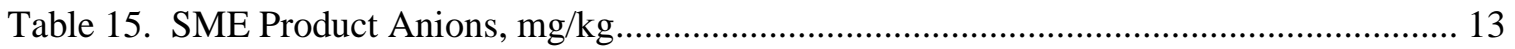

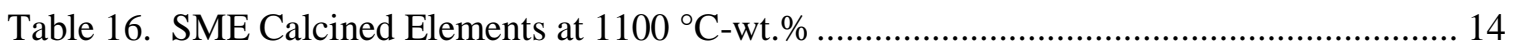

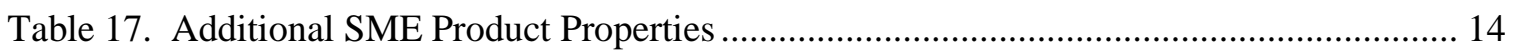

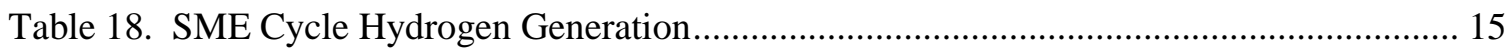

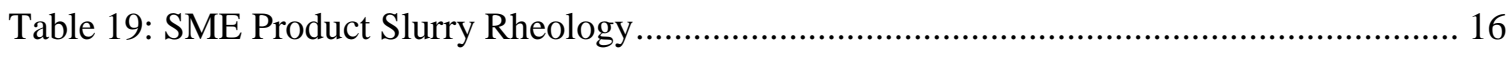

\section{LIST OF FIGURES}

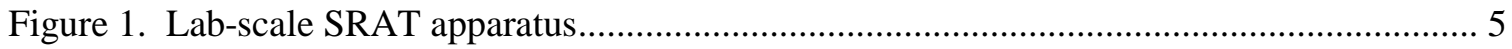

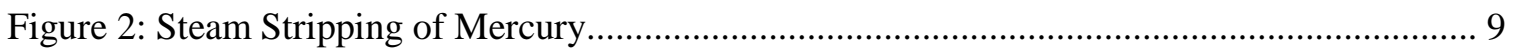

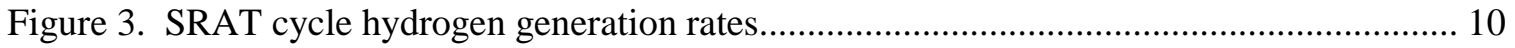

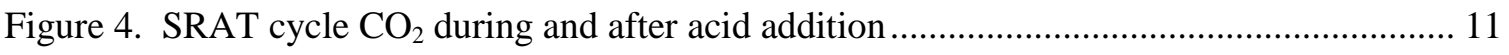

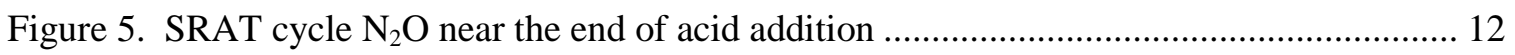

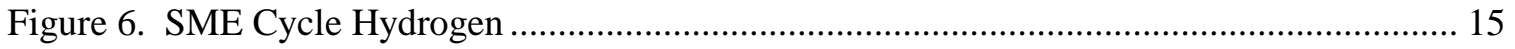

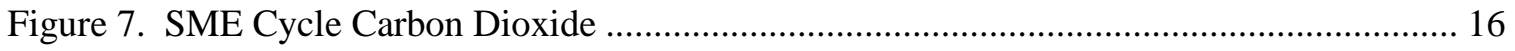


SRNL-STI-2012-00620

Revision 0

\section{LIST OF ABBREVIATIONS}

$\begin{array}{ll}\text { SRNL } & \text { Savannah River National Laboratory } \\ \text { AD } & \text { Analytical Development } \\ \text { ARP } & \text { Actinide Removal Process } \\ \text { BDL } & \text { Below Detection Limit } \\ \text { CPC } & \text { Chemical Process Cell } \\ \text { CSTR } & \text { Continuously Stirred Tank Reactor } \\ \text { DWPF } & \text { Defense Waste Processing Facility } \\ \text { EE } & \text { Electron Equivalent } \\ \text { FAVC } & \text { Formic Acid Vent Collector } \\ \text { GC } & \text { Gas Chromatograph } \\ \text { ICP-AES } & \text { Ion Coupled Plasma - Atomic Emission Spectrometry } \\ \text { KMA } & \text { Koopman Minimum Acid } \\ \text { MCU } & \text { Modular Caustic Side Solvent Extraction Unit } \\ \text { MWWT } & \text { Mercury Water Wash Tank } \\ \text { PSAL } & \text { Process Science Analytical Laboratory } \\ \text { PTP } & \text { Process Technology Programs } \\ \text { SB } & \text { Sludge Batch } \\ \text { SME } & \text { Slurry Mix Evaporator } \\ \text { SRAT } & \text { Sludge Receipt and Adjustment Tank } \\ \text { TIC } & \text { Total Inorganic Carbon } \\ \text { TTQAP } & \text { Task Technical and Quality Assurance } \\ \text { TTR } & \text { Technical Task Request } \\ \text { WL } & \text { Waste Loading }\end{array}$




\subsection{Introduction}

Prior to processing a Sludge Batch (SB) in the Defense Waste Processing Facility (DWPF), flowsheet studies using simulants are performed. Typically, the flowsheet studies are conducted based on projected composition(s). The results from the flowsheet testing are used to 1) guide decisions during sludge batch preparation, 2) serve as a preliminary evaluation of potential processing issues, and 3) provide a basis to support the Shielded Cells qualification runs performed at the Savannah River National Laboratory (SRNL). The initial composition for SB8 included the heel of Tank 40 (Sludge Batch 7b), Tank 13, Tank 12 (neutralized oxalic acid cleaning solution), Tank 51 heel and neutralized plutonium solution from $\mathrm{H}$ - Canyon. Sludge batches processed at DWPF are typically processed with monosodium titanate (MST)/sludge solids from the Actinide Removal Process (ARP) and Strip Effluent from the Modular Caustic-side solvent extraction Unit (MCU).

For each sludge batch that is processed in DWPF, SRNL has performed non-radioactive and radioactive sludge runs to evaluate potential chemical processing issues, quantify the potential hydrogen generation rates that could be seen in DWPF, and to estimate the required acid stoichiometry for that sludge batch. As necessary, DWPF modifies its operating flowsheet to adjust for processing of the incoming or existing sludge batch.

Waste Solidification Engineering has issued TTR HLW-DWPF-TTR-2012-0004 to SRNL to perform flowsheet studies for SB8. In particular, the TTR requests SRNL to validate the existing sludge-only flowsheet and establish a coupled operations (sludge with ARP and/or MCU strip effluent) flowsheet for use with SB8. Of particular interest for SB8 is the impact of oxalate potentially coming from Tank 12.

The SRAT/SME runs were performed to mimic the DWPF SB8 flowsheet process. Initial studies used projected noble metals levels to attempt to bound the acid addition level for the target washing endpoints. Testing was performed to help define an acceptable processing window between acceptable nitrite destruction and hydrogen generation, while also considering slurry rheology.

This report will present data from six non-coupled process simulations, four from Tk 40, and two from Tk 51.

\subsection{Experimental Procedure}

\subsection{Process and Sample Analytical Methods}

The automated data acquisition system developed for the 4-L SRAT rigs was used to collect electronic data on a computer ${ }^{2}$. Collected data included slurry temperature, bath temperatures for the cooling water to the SRAT condenser and Formic Acid Vent Condenser (FAVC), slurry pH, mixer speed and torque, air and helium purge flows. Helium is used as an internal standard and is set to $0.5 \%$ of the nominal air purge flow. Cumulative acid addition volume data were collected using an algorithm for pump speed and time versus volume delivered. Raw Gas Chromatograph (GC) data were acquired on a separate computer interfaced to the data acquisition computer.

Agilent 3000A micro GC's were used for all runs. The GC's were baked out prior to the runs each week. Column-A can collect data related to $\mathrm{He}, \mathrm{H}_{2}, \mathrm{O}_{2}, \mathrm{~N}_{2}$, NO, and $\mathrm{CO}$, while column-B can collect data related to $\mathrm{CO}_{2}, \mathrm{~N}_{2} \mathrm{O}$, and water. GC's were calibrated with a standard calibration gas containing 0.510 vol\% He, 1.000 vol\% $\mathrm{H}_{2}$, 20.10 vol\% $\mathrm{O}_{2}, 50.77$ vol\% $\mathrm{N}_{2}$, 25.1 vol\% $\mathrm{CO}_{2}$ 
and 2.52 vol\% $\mathrm{N}_{2} \mathrm{O}$. The calibration was verified prior to starting the SRAT cycle and after completing the Slurry Mix Evaporator (SME) cycle. Room air was used to give a two point calibration for $\mathrm{N}_{2}$ and to check the calibration. The chilled off-gas leaving the FAVC was passed through a Nafion dryer in counter-current flow with a dried air stream to reduce the moisture content at the GC inlet. The dried, chilled off-gas stream was sampled by a GC from the beginning of heat-up to temperature to start the SRAT cycle through most of the cool down following the SME cycle.

Process samples were analyzed by various methods. Slurry and supernate elemental compositions were determined by inductively coupled plasma-atomic emission spectroscopy (ICP-AES) after lithium metaborate and sodium peroxide fusions at the Process Science Analytical Laboratory (PSAL). Slurry samples were calcined at $1100^{\circ} \mathrm{C}$. The main advantage of this approach was to permit easier comparisons between SRAT product elements and sludge elements. Noble metals and mercury were trimmed uniquely to each SRAT, and their concentrations are known more accurately from material balance considerations than they could be from ICP-AES analyses.

Water soluble slurry anions were determined by ion chromatography (IC) on 100-fold weighted dilutions of slurry with water followed by filtration to remove the remaining insoluble solids. SRAT cycle, SRAT product, and SME product slurry samples were submitted to PSAL for mercury analysis by ICP-AES. Samples were submitted to Analytical Development (AD) for total inorganic carbon analysis of both the starting slurry and the supernate. Samples were analyzed by PSAL for slurry and supernate density using the Anton-Parr DM-4500 instrument. Starting sludges were titrated to $\mathrm{pH} 7$ using an auto-titrator to determine the base equivalents for input into the stoichiometric acid equation. Samples from the ammonia scrubber reservoir vessel were analyzed by $\mathrm{AD}$ using cation chromatography for ammonium ion.

Gas chromatograph off-gas data were scaled to DWPF flow rates. The calculation methodology has been previously documented. ${ }^{3}$ An internal standard flow was established with helium. Other gas flow rates were determined relative to helium by taking the ratio of the two gas volume percentages times the helium standard flow. The results were scaled by the ratio of 6,000 gallons of fresh sludge divided by the volume of fresh sludge in the simulant SRAT charge.

\subsection{Simulant Preparation and Characterization}

The test simulant was prepared from blends of Tank 4, Tank 7, and Tank 12 simulants originally prepared for SB7a and SB7b testing. The simulant was fabricated by the continuous stirred tank reactor (CSTR) precipitation method. ${ }^{4}$ This method involved the following processing steps:

- A slurry of precipitated $\mathrm{MnO}_{2}$ was prepared.

- An acidic metal nitrate solution was prepared.

- The precipitated $\mathrm{MnO}_{2}$ was combined with and acidic metal nitrate solution.

- The combined solution and a $50 \mathrm{wt} \%$ sodium hydroxide solution were separately fed to the CSTR to produce a slurry of hydrous metal oxide and hydroxide solids in a sodium nitrate solution at a $\mathrm{pH}$ of about 9.5 .

- The slurry was contacted with sodium carbonate to permit conversion of some of the hydroxides to carbonates.

- The slurry was decanted and washed until the nitrate concentration was below the target supernate nitrate concentration.

- The slurry was concentrated to a point consistent with the targeted total solids value for the final slurry. 
- Silica, $\mathrm{TiO}_{2}$, and soluble salts were added to complete the preparation.

This simulant was split into two batches that were adjusted to supernate compositions projected for SB8 in Tank 40 at sodium molarities. Table 1 presents the average elemental results of duplicate analyses of two slurry samples from the test simulant calcined at $1100^{\circ} \mathrm{C}$.

Table 1. Elemental composition of SRAT feeds calcined at $1100^{\circ} \mathrm{C}$, wt $\%$

\begin{tabular}{|c|c|c|}
\hline Element & $\begin{array}{c}\text { Tank 40 } \\
\text { Simulant }\end{array}$ & $\begin{array}{c}\text { Tank 51 } \\
\text { Simulant }\end{array}$ \\
\hline $\mathrm{Al}$ & 8.21 & 6.51 \\
\hline $\mathrm{Ba}$ & 0.11 & 0.11 \\
\hline $\mathrm{Ca}$ & 1.59 & 1.85 \\
\hline $\mathrm{Ce}$ & 0.32 & 0.38 \\
\hline $\mathrm{Cr}$ & 0.30 & 0.41 \\
\hline $\mathrm{Cu}$ & 0.05 & 0.04 \\
\hline $\mathrm{Fe}$ & 23.16 & 24.92 \\
\hline $\mathrm{K}$ & 0.84 & 1.15 \\
\hline $\mathrm{La}$ & 0.07 & 0.05 \\
\hline $\mathrm{Mg}$ & 0.31 & 0.27 \\
\hline $\mathrm{Mn}$ & 7.90 & 9.39 \\
\hline $\mathrm{Na}$ & 17.35 & 17.68 \\
\hline $\mathrm{Ni}$ & 1.87 & 1.17 \\
\hline $\mathrm{Pb}$ & 0.05 & 0.05 \\
\hline $\mathrm{S}$ & 0.46 & 0.37 \\
\hline $\mathrm{Si}$ & 1.36 & 1.31 \\
\hline $\mathrm{Th}$ & 1.11 & 0.97 \\
\hline $\mathrm{Ti}$ & 0.02 & 0.02 \\
\hline $\mathrm{Zn}$ & 0.04 & 0.03 \\
\hline $\mathrm{Zr}$ & 0.20 & 0.18 \\
\hline
\end{tabular}

Table 2 presents results for total, insoluble, soluble and calcined wt.\% solids, slurry and supernate density, slurry base equivalent molarity, slurry and supernate total inorganic carbon (TIC), and the slurry anion results from IC. The high sodium test simulant values are compared to the SB7b WAPS sample. 
Table 2. Simulant and Radioactive Feed Properties

\begin{tabular}{|l|c|c|c|}
\hline & $\begin{array}{c}\text { SB7b } \\
\text { WAPS }\end{array}$ & $\begin{array}{c}\text { Tank 40 } \\
\text { Simulant }\end{array}$ & $\begin{array}{c}\text { Tank 51 } \\
\text { Simulant }\end{array}$ \\
\hline Total solids, wt.\% & 15.6 & 20.68 & 24.78 \\
\hline Insoluble solids, wt.\% & 10.8 & 12.51 & 14.33 \\
\hline Soluble solids, wt.\% & 5.48 & 8.18 & 10.45 \\
\hline Calcined solids, wt.\% & 12.5 & 15.61 & 18.72 \\
\hline Slurry density, g/mL & 1.12 & 1.18 & 1.20 \\
\hline Supernate density, g/mL & 1.05 & 1.08 & 1.09 \\
\hline Slurry base equiv., mol/kg & 0.29 & 0.930 & 1.154 \\
\hline Nitrite, mg/kg slurry & 9,120 & 16,500 & 21,900 \\
\hline Nitrate, mg/kg slurry & 5,100 & 10,550 & 14,400 \\
\hline Sulfate, mg/kg slurry & 1,470 & 1,880 & 2,050 \\
\hline Oxalate, mg/kg slurry & 2,970 & 6,600 & 6,190 \\
\hline Chloride, mg/kg slurry & $<400$ & $<400$ & $<400$ \\
\hline Slurry TIC, mg/kg slurry & 1,610 & 2,200 & 1,010 \\
\hline Supernate TIC, mg/L supernate & 1,120 & 1,560 & 1,290 \\
\hline
\end{tabular}

The high sodium simulant SRAT simulations started with approximately 3,300 g for Tank 40 sludge and 3,000 g of Tank 51 starting sludge (before minor trim chemicals and rinse water). These were sludge-only tests and did not include coupled processing with streams from the Modular Caustic Side Solvent Extraction Unit (MCU/ARP) and the Actinide Removal Process (ARP).

Accurate projections for mercury and noble metals in SB8 sludge were not available prior to the acid window simulant testing. Conservative estimates of the noble metal and mercury concentrations for SB8 Tank 51 and Tank 40 simulants were based on the measured concentrations in the SB7b WAPS sample ${ }^{5}$ and the washed SB8 Tank 51 qualification sample. The SB8 Tank 40 blend was projected to be $42.7 \%$ SB7b heel on a total solids mass basis. Noble metals were trimmed at $125 \%$ of the estimated values while mercury was trimmed at $110 \%$.

SB7b levels of mercury and noble metals were used and adjusted for dilution due to increased sodium. Rhodium was trimmed as a solution of $\mathrm{Rh}\left(\mathrm{NO}_{3}\right)_{3}$ containing $4.93 \mathrm{wt}$.\% Rh. Ruthenium was added as the dry trivalent chloride salt at a purity of $41.74 \mathrm{wt} \%$ Ru. Palladium was trimmed as a solution of $\mathrm{Pd}\left(\mathrm{NO}_{3}\right)_{2}$ containing 15.27 wt.\% Pd. Silver was added as the dry nitrate salt $\mathrm{AgNO}_{3}$. Mercury was trimmed as dry $\mathrm{HgO}$ (yellow mercuric oxide, which is more finely ground than red mercuric oxide).

Targets for the two test simulants are given in Table 3 along with the reported values for the SB7b WAPS sample for comparison. 
Table 3. Noble metal and mercury, wt\% in total solids

\begin{tabular}{|l|c|c|c|}
\hline & $\begin{array}{c}\text { SB7b } \\
\text { WAPS }\end{array}$ & $\begin{array}{c}\text { Tank 40 } \\
\text { Simulant }\end{array}$ & $\begin{array}{c}\text { Tank 51 } \\
\text { Simulant }\end{array}$ \\
\hline $\mathrm{Hg}, \mathrm{wt} \%$ & 1.710 & 2.32 & 2.54 \\
\hline $\mathrm{Rh}, \mathrm{wt} \%$ & 0.0207 & 0.0157 & 0.0111 \\
\hline $\mathrm{Ru}, \mathrm{wt} \%$ & 0.102 & 0.0668 & 0.0427 \\
\hline $\mathrm{Pd}, \mathrm{wt} \%$ & 0.0025 & 0.0009 & 0.0002 \\
\hline $\mathrm{Ag}, \mathrm{wt} \%$ & 0.0118 & 0.0148 & 0.0140 \\
\hline
\end{tabular}

\subsection{Chemical Process Cell Simulation Details}

The trimmed SRAT receipt volume was about 3.0 L for the high sodium testing. The 4-L labscale SRAT equipment was used for these tests. A photo of the 4-L rig is shown in Figure 1. Details about the design are in the CPC equipment set-up reference. ${ }^{6}$

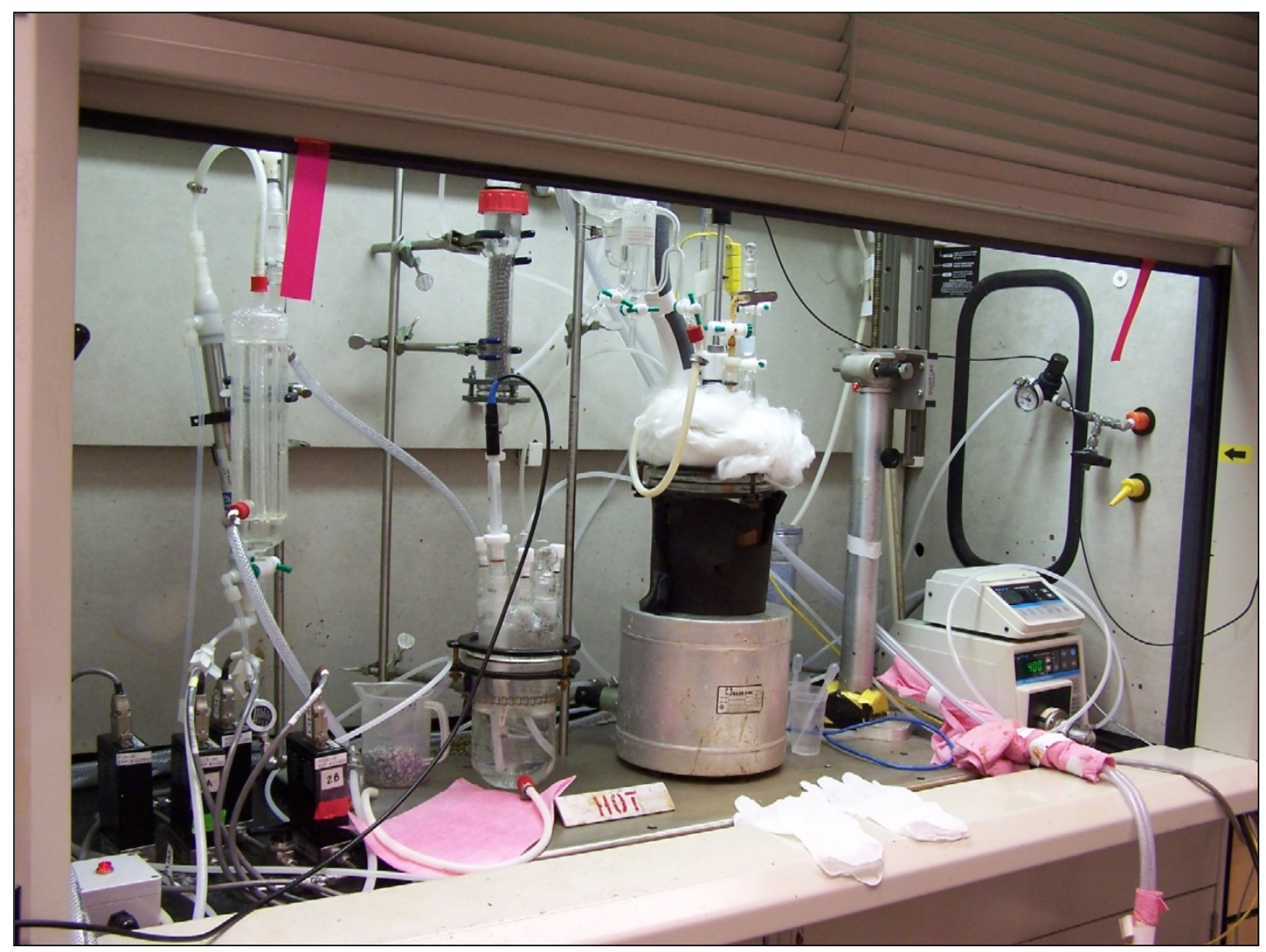

Figure 1. Lab-scale SRAT apparatus

The reservoir below the ammonia scrubber was charged with a solution of $749 \mathrm{~g}$ of de-ionized water and $1 \mathrm{~g}$ of $50 \mathrm{wt} . \%$ nitric acid. The dilute acid reservoir solution was recirculated by a MasterFlex driven Micropump gear pump at about $300 \mathrm{~mL}$ per minute to a spray nozzle at the top of the packed section. 
Initial acid calculations were based on the Koopman minimum acid (KMA) requirement equation. $^{7}$

$$
\frac{\text { moles acid }}{L \text { slurry }}=\text { base equivalents }+\mathrm{Hg}+\text { soluble } \mathrm{TIC}+1.5 *(\mathrm{Ca}+\mathrm{Mg})+1.0 * \text { nitrite }+1.5 * \mathrm{Mn}
$$

Four different stoichiometric factors were used in the acid calculations, $100 \%, 110 \%, 125 \%$, and $130 \%$. Run identification for these experiments used the nominal Tank 51 sodium concentration followed by the percent acid stoichiometry. Acid calculations were also performed using the current DWPF algorithm for comparison: ${ }^{8}$

$$
\frac{\text { moles acid }}{L \text { slurry }}=\text { base equivalents }+2 * \text { total TIC }+0.75 * \text { nitrite }+1.2 * \mathrm{Mn}+\mathrm{Hg}
$$

The results of these two calculations for the simulants are summarized in Table 4. SB8-A1, A2, A3, and A4 represent Tank 40 process simulations, while SB8-B1 and B2 represent Tank 51. The runs are presented in order of increasing acid stoichiometry. The table also includes the actual acid additions made based on the Koopman minimum acid equation (maximum acid) and the equivalent DWPF stoichiometric factors (percent) to go from the DWPF acid equation values to the actual acid additions. The total acid was partitioned between formic and nitric acids using the current RedOx equation ${ }^{9}$ containing an electron equivalent (EE) term of 5 for manganese. This resulted in slightly more formic acid and less nitric acid being added compared to using an EE term of 2 for manganese.

Table 4. Stoichiometric acid calculation results, moles acid/L trimmed slurry

\begin{tabular}{|l|c|c|c|c|}
\hline & $\begin{array}{c}\text { DWPF Eqn. } \\
\text { moles/L }\end{array}$ & $\begin{array}{c}\text { Koopman Min. } \\
\text { moles/L }\end{array}$ & KMA Factor & Equivalent DWPF factor \\
\hline SB8-A1 & 2.011 & 2.026 & $110 \%$ & $110 \%$ \\
\hline SB8-A3 & 2.011 & 2.026 & $110 \%$ & $110 \%$ \\
\hline SB8-B1 & 2.272 & 2.615 & $110 \%$ & $126 \%$ \\
\hline SB8-A2 & 2.011 & 2.026 & $136 \%$ & $137 \%$ \\
\hline SB8-A4 & 2.011 & 2.026 & $146 \%$ & $147 \%$ \\
\hline SB8-B2 & 2.272 & 2.615 & $146 \%$ & $168 \%$ \\
\hline
\end{tabular}

Scaling was based on DWPF design basis SRAT/SME processing conditions. The SRAT and SME cycles, however, did not have a heel from a prior batch. R\&D directions were prepared for each run and used to supplement the standard SRNL procedure for non-radioactive CPC simulations. ${ }^{10}$ The following parameters were used:

- The SRAT air purge scaled to $230 \mathrm{scfm}$ in DWPF.

- A 200 ppm antifoam addition was made prior to nitric acid addition.

- A 100 ppm antifoam addition was made prior to formic acid addition.

- $\quad$ Nitric and formic acid addition were made at $93^{\circ} \mathrm{C}$.

- Acids were added at two gallons per minute scaled per the discussion below.

- A 500 ppm antifoam addition was made prior to going to boiling following acid addition.

- Boiling assumed a condensate production rate of 5,000 lb/hr at DWPF scale. 
- $\quad$ SRAT dewatering took about 2-3 hours to produce a 26-28 wt\% total solids slurry.

- Reflux followed dewatering. The end of the 12-hour reflux period defined the end of the SRAT cycle (theoretically this was sufficient to strip mercury to specifications).

- The SME air purge scaled to 74 scfm in DWPF.

- A 100 ppm antifoam addition was made at the start of the SME cycle.

- Canister decontamination water additions and dewaterings were not simulated.

- Two frit 418-water-formic acid additions were made targeting 36\% waste loading.

- The SME was dewatered following each frit slurry addition.

- The final SME solids target was 45-49 wt\%.

Samples were taken during each SRAT cycle to monitor the progress of the main reactions. Major cations and anions were checked immediately after acid addition. Samples were pulled during boiling to monitor suspended and dissolved mercury in the SRAT slurry. These samples were pulled directly into digestion vials to eliminate potential segregation of mercury during subsampling/aliquoting steps. The SRAT and SME product slurries were sampled similarly once they had cooled to $90{ }^{\circ} \mathrm{C}$ while the vessel contents were still mixing.

Additional SRAT product samples were taken for compositional and solids analyses after the product had cooled further. The Mercury Water Wash Tank (MWWT) and FAVC were drained and the condensates weighed after both the SRAT and SME cycles.

\subsection{Results and Discussion}

\subsection{SRAT Cycle}

The six simulant SRAT cycles are discussed below. Chemical and physical data from process samples will be presented first followed by off-gas data.

\subsubsection{SRAT Cycle Slurry Samples}

Typically, up to one-third of the nitrite is converted to nitrate, with the remainder converting to $\mathrm{NO}_{\mathrm{x}}$ and $\mathrm{N}_{2} \mathrm{O}$. Formate is destroyed by the reduction of $\mathrm{Mn}, \mathrm{Hg}$, and catalytic destruction of nitrite ion to produce $\mathrm{NO}, \mathrm{N}_{2} \mathrm{O}, \mathrm{NO}_{2}$, and $\mathrm{CO}_{2}$. Formic acid is catalytically destroyed to produce $\mathrm{CO}_{2}$ and hydrogen. Oxalate analyses continue to show high variation ${ }^{11}$ and were not included. Formate loss and nitrite/nitrate results are presented in Table 5 for the SRAT product.

Table 5. SRAT Anion Reactions

\begin{tabular}{|l|c|c|c|c|c|c|}
\hline & SB8-A1 & SB8-A3 & SB8-B1 & SB8-A2 & SB8-A4 & SB8-B2 \\
\hline KMA stoichiometry, \% & 110 & 110 & 110 & 136 & 146 & 146 \\
\hline Formate loss, \% & 26 & 28 & 26 & 27 & 37 & 32 \\
\hline Nitrite-to-nitrate, \% & 16 & 16 & 27 & 19 & 8.9 & 17 \\
\hline Nitrite loss, \% & 97 & 97 & 99 & 97 & 97 & 99 \\
\hline
\end{tabular}

The low nitrite-to-nitrate conversion numbers suggest ammonium ion formation was occurring during boiling $^{12}$. Table 6 reports the anion analytical data for the SRAT products. The acid stoichiometry tested met the nitrite constraint of $<1000 \mathrm{mg} / \mathrm{kg}$ slurry by destroying all nitrite. 
Table 6. SRAT Product Anions, mg/kg slurry

\begin{tabular}{|c|c|c|c|c|c|c|}
\hline Anions & SB8-A1 & SB8-A3 & SB8-B1 & SB8-A2 & SB8-A4 & SB8-B2 \\
\hline KMA stoichiometry, \% & 110 & 110 & 110 & 136 & 146 & 146 \\
\hline $\mathrm{NO}_{2}{ }^{-}$ & $<500$ & $<500$ & $<500$ & $<500$ & $<500$ & $<500$ \\
\hline $\mathrm{NO}_{3}{ }^{-}$ & 30,800 & 31,150 & 36,300 & 29,550 & 31,200 & 34,250 \\
\hline $\mathrm{SO}_{4}{ }^{-}$ & 950 & 1,080 & 1,030 & 1,310 & 1,600 & 2,690 \\
\hline $\mathrm{HCO}_{2}^{-}$ & 57,600 & 57,000 & 65,600 & 78,300 & 76,150 & 81,550 \\
\hline
\end{tabular}

Elemental wt.\% data for the six SRAT products calcined at $1100{ }^{\circ} \mathrm{C}$ are given in Table 7.

Table 7. SRAT Calcined Elements at $1100{ }^{\circ} \mathrm{C}-w t . \%$

\begin{tabular}{|c|c|c|c|c|c|c|}
\hline Run ID & SB8-A1 & SB8-A3 & SB8-B1 & SB8-A2 & SB8-A4 & SB8-B2 \\
\hline $\mathrm{Al}$ & 7.83 & 8.01 & 6.61 & 7.55 & 8.23 & 5.83 \\
\hline $\mathrm{Ba}$ & 0.101 & 0.103 & 0.09 & 0.097 & 0.108 & 0.084 \\
\hline $\mathrm{Ca}$ & 1.64 & 1.69 & 1.60 & 1.60 & 1.40 & 1.59 \\
\hline $\mathrm{Ce}$ & 0.294 & 0.301 & 0.33 & 0.281 & 0.318 & 0.316 \\
\hline $\mathrm{Cr}$ & 0.221 & 0.228 & 0.45 & 0.211 & 0.240 & 0.208 \\
\hline $\mathrm{Cu}$ & 0.038 & 0.030 & 0.03 & 0.049 & 0.030 & 0.012 \\
\hline $\mathrm{Fe}$ & 22.4 & 22.7 & 23.6 & 21.5 & 23.1 & 22.5 \\
\hline $\mathrm{K}$ & 0.292 & 0.334 & 0.37 & 0.315 & 0.350 & 0.352 \\
\hline $\mathrm{La}$ & 0.064 & 0.066 & 0.05 & 0.064 & 0.069 & 0.047 \\
\hline $\mathrm{Mg}$ & 0.264 & 0.269 & 0.22 & 0.253 & 0.264 & 0.227 \\
\hline $\mathrm{Mn}$ & 7.39 & 7.54 & 9.29 & 7.26 & 4.94 & 13.6 \\
\hline $\mathrm{Na}$ & 19.3 & 19.3 & 18.65 & 18.9 & 20.6 & 16.3 \\
\hline $\mathrm{Ni}$ & 1.81 & 1.86 & 1.10 & 1.77 & 1.80 & 1.13 \\
\hline $\mathrm{Pb}$ & $<0.01$ & 0.018 & 0.02 & 0.014 & 0.02 & 0.013 \\
\hline $\mathrm{S}$ & 0.366 & 0.377 & 0.31 & 0.351 & 0.389 & 0.292 \\
\hline $\mathrm{Si}$ & 1.28 & 1.33 & 1.18 & 1.21 & 1.42 & 1.32 \\
\hline $\mathrm{Ti}$ & 0.018 & 0.018 & 0.02 & 0.016 & 0.019 & 0.014 \\
\hline $\mathrm{Zn}$ & 0.153 & 0.153 & 0.03 & 0.138 & 0.158 & 0.031 \\
\hline $\mathrm{Zr}$ & 0.141 & 0.142 & 0.15 & 0.127 & 0.144 & 0.149 \\
\hline
\end{tabular}

SRAT product solids data, densities, and $\mathrm{pH}$ are given in Table 8 . The wt.\% insoluble and soluble solids were calculated from the measured total slurry and supernate (dissolved) solids. The density measurements were made at $25^{\circ} \mathrm{C}$.

Table 8. Additional SRAT Product Properties

\begin{tabular}{|l|c|c|c|c|c|c|}
\hline Run ID: & SB8-A1 & SB8-A3 & SB8-B1 & SB8-A2 & SB8-A4 & SB8-B2 \\
\hline Wt. \% total solids & 25.85 & 26.18 & 27.23 & 28.01 & 29.77 & 27.51 \\
\hline Wt. \% insoluble solids & 12.36 & 13.12 & 11.91 & 12.82 & 15.58 & 11.86 \\
\hline Wt. \% soluble solids & 13.49 & 13.06 & 15.32 & 15.20 & 14.19 & 15.65 \\
\hline Wt. \% calcined solids & 16.43 & 16.64 & 17.42 & 17.19 & 18.28 & 17.08 \\
\hline Slurry density, g/mL & 1.200 & 1.205 & 1.215 & 1.221 & 1.219 & 1.210 \\
\hline Supernate density, g/mL & 1.093 & 1.093 & 1.109 & 1.116 & 1.114 & 1.119 \\
\hline Product pH at $25^{\circ} \mathrm{C}$ & 7.78 & 7.72 & 7.78 & 6.49 & 5.92 & 7.62 \\
\hline
\end{tabular}




\subsubsection{Mercury}

Mercury concentration in the SRAT was tracked as a function of time during the process simulations in order to evaluate steam stripping. Figure 2 shows how well the mercury was removed of the time frame of the SRAT cycle. Sharp increases or decreases in mercury concentration, as seen in SB8-A4, can be attributed to sampling error (inadequate dispersion of the mercury bead).

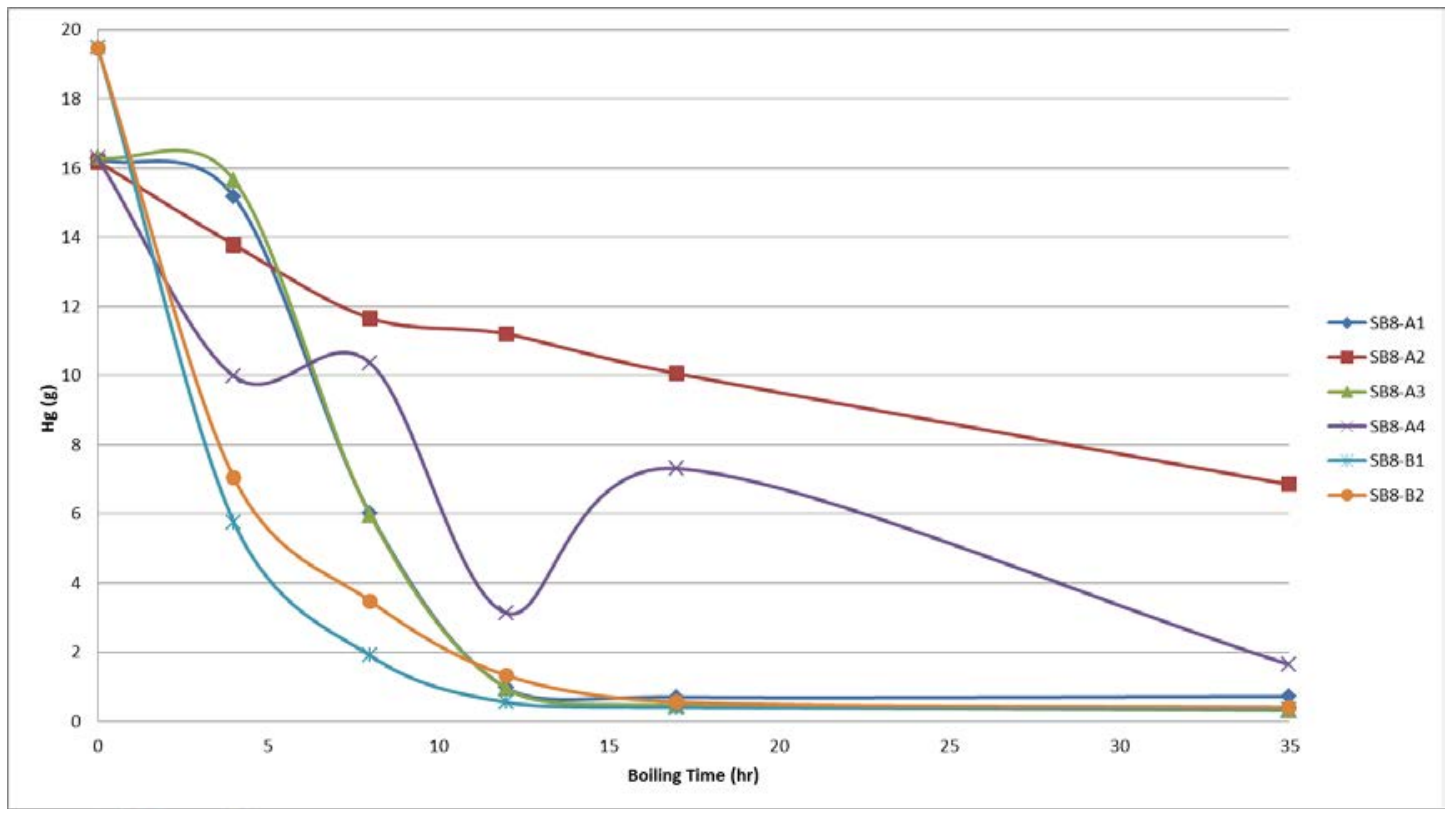

Figure 2: Steam Stripping of Mercury

SRAT product must be below $0.8 \mathrm{wt} \%$ (solids basis) mercury to meet process specifications. All runs were within the mercury limit.

\begin{tabular}{|l|c|c|c|c|c|c|}
\hline Run ID: & SB8-A1 & SB8-A2 & SB8-A3 & SB8-A4 & SB8-B1 & SB8-B2 \\
\hline Concentration, mg Hg/kg slurry & 217 & 2155 & 93 & 588 & 119 & 136 \\
\hline Wt\% Hg in solids & 0.084 & 0.769 & 0.036 & 0.197 & 0.044 & 0.050 \\
\hline
\end{tabular}

Table 9: SRAT Product Mercury

\subsubsection{Foaming}

To prevent foaming during the SRAT cycle, $200 \mathrm{ppm}$ of ITT 747 antifoam was added prior to nitric acid addition. An additional $100 \mathrm{ppm}$ antifoam was added prior to formic acid addition. $500 \mathrm{ppm}$ antifoam was added after acid addition, just prior to boiling. No foaming was observed during any of the SRAT cycles.

To prevent foaming during the SME cycles, $100 \mathrm{ppm}$ antifoam was added. No foaming was observed during any of the SME cycles.

\subsubsection{SRAT Off-gas Data}

Three factors that influence hydrogen production during CPC include: 
1. The amount of formic acid added - formic acid catalytically decomposes into carbon dioxide and hydrogen gas in the presence of noble metals. As formic acid concentrations increase, the rate of production of hydrogen gas also increases. This increase is due to there being more formic acid available to activate the noble metal catalysts and undergo decomposition.

2. SRAT temperature - increasing temperature increases the rate at which chemical reactions occur, causing the decomposition reaction of formic acid to occur more rapidly.

3. Formic acid addition rate - as the rate of formic acid addition increase, the rate of hydrogen gas increases due to the increased rate of catalyst activation by formic acid.

The DWPF-scale hydrogen generation rates during the SRAT cycle are given in Figure 3. Hydrogen generation is initiated by rhodium activation. Hydrogen production due to ruthenium occurs later in the SRAT cycle after nitrite destruction, as can be seen in the high acid runs in Figure 3.

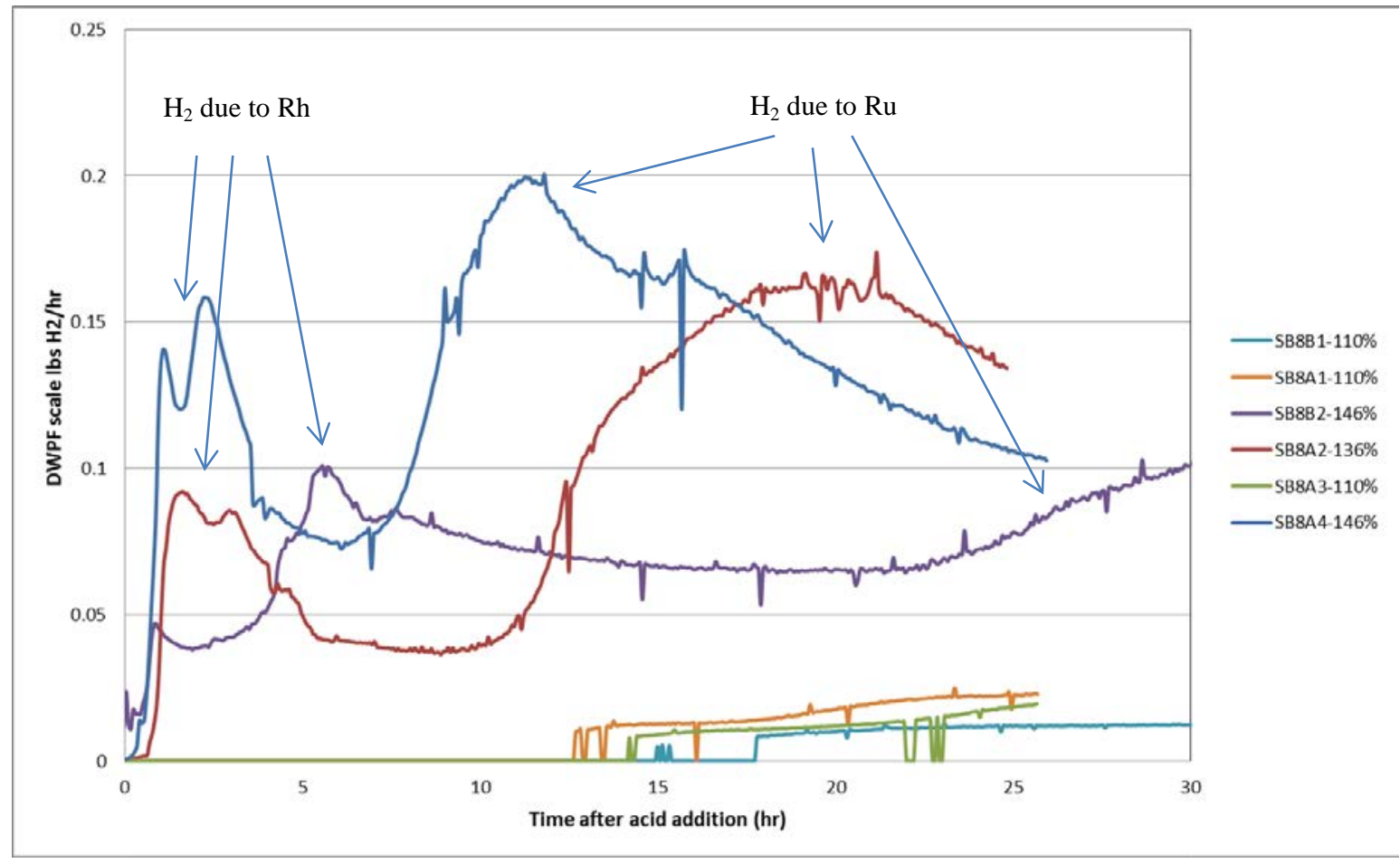

Figure 3. SRAT cycle hydrogen generation rates

The three lower acid runs had little to no hydrogen generation. As the acid stoichiometric factor increased, so did hydrogen generation. None of the six SRAT runs exceeded the DWPF SRAT hydrogen limit $(0.65 \mathrm{lb} / \mathrm{hr})$. Table 10 presents numerical data for the amounts of hydrogen generated during the SRAT cycles.

Table 10. SRAT Cycle Hydrogen Generation

\begin{tabular}{|l|c|c|c|c|c|c|}
\hline Run ID: & SB8-A1 & SB8-A3 & SB8-B1 & SB8-A2 & SB8-A4 & SB8-B2 \\
\hline Peak hydrogen, lb/h & 0.025 & 0.020 & 0.013 & 0.174 & 0.201 & 0.101 \\
\hline \% of SRAT limit & 3.8 & 3.1 & 2.0 & 28 & 31 & 16 \\
\hline
\end{tabular}

The carbon dioxide gas generation rate profiles are given in Figure 4. 


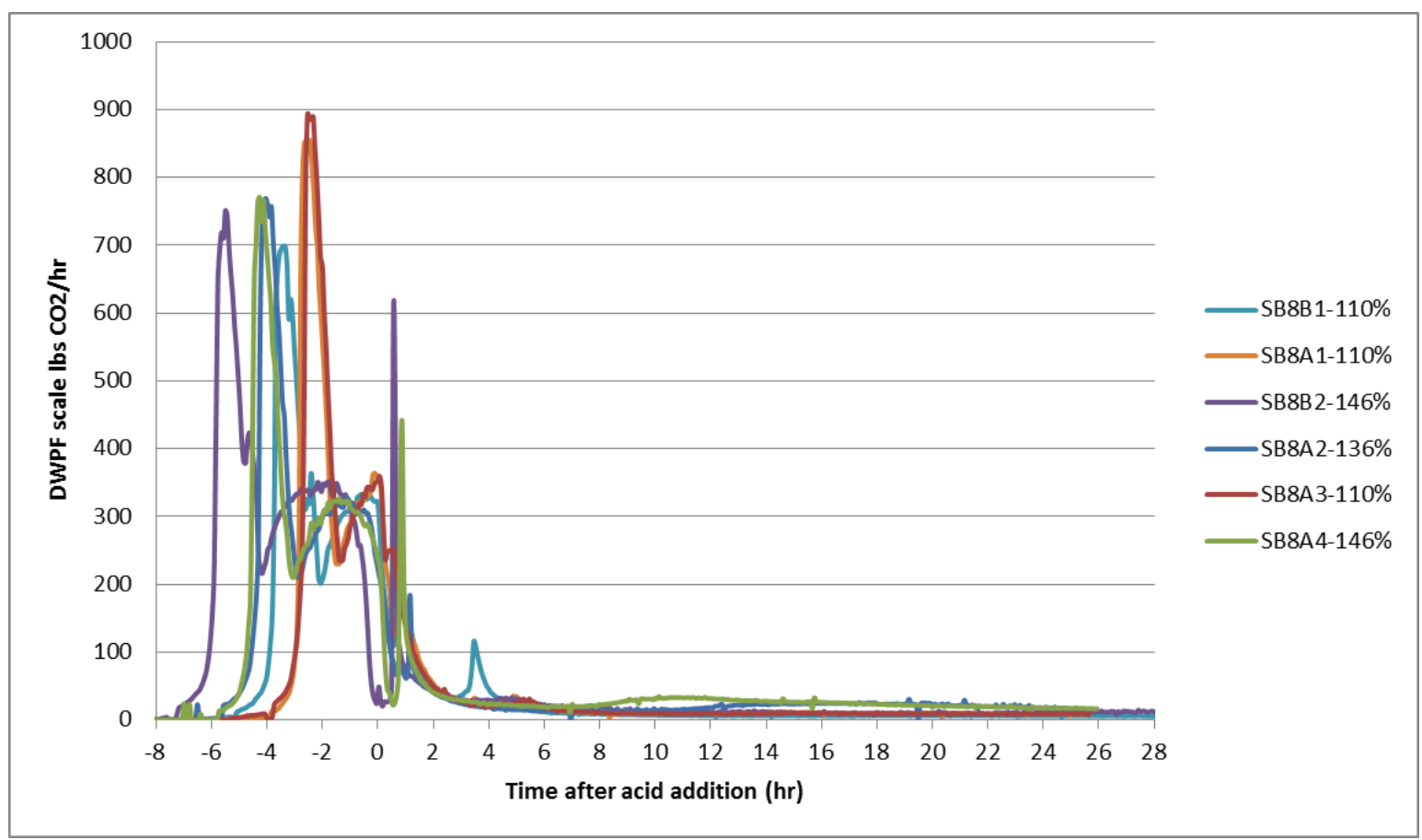

Figure 4. SRAT cycle $\mathrm{CO}_{2}$ during and after acid addition

Peaks in $\mathrm{CO}_{2}$ during boiling align with peaks in $\mathrm{H}_{2}$, as can be seen just prior to the 5 hour time. The $\mathrm{CO}_{2}$ traces are similar in peak height and shape during acid addition with exceptions made for the greater offgas occurring during formic acid decomposition for the higher acid runs and the somewhat longer acid addition time at higher stoichiometries. Numerical results for carbon dioxide generation are given in Table 11.

Table 11. SRAT Cycle Carbon Dioxide Generation

\begin{tabular}{|l|c|c|c|c|c|c|}
\hline Run ID: & SB8-A1 & SB8-A3 & SB8-B1 & SB8-A2 & SB8-A4 & SB8-B2 \\
\hline Peak $\mathrm{CO}_{2}, \mathrm{lb} / \mathrm{h}$ & 854 & 893 & 699 & 769 & 771 & 751 \\
\hline Max vol\% & 30.9 & 31.7 & 28.6 & 32.3 & 32.8 & 30.6 \\
\hline Total $\mathrm{CO}_{2}$, g & 99.6 & 99.4 & 105 & 118 & 128 & 143 \\
\hline
\end{tabular}

Off-gas data for $\mathrm{N}_{2} \mathrm{O}$ are presented in a similar manner to the data for $\mathrm{CO}_{2}$. A high range graph covering the period around acid addition is given in Figure 5. 


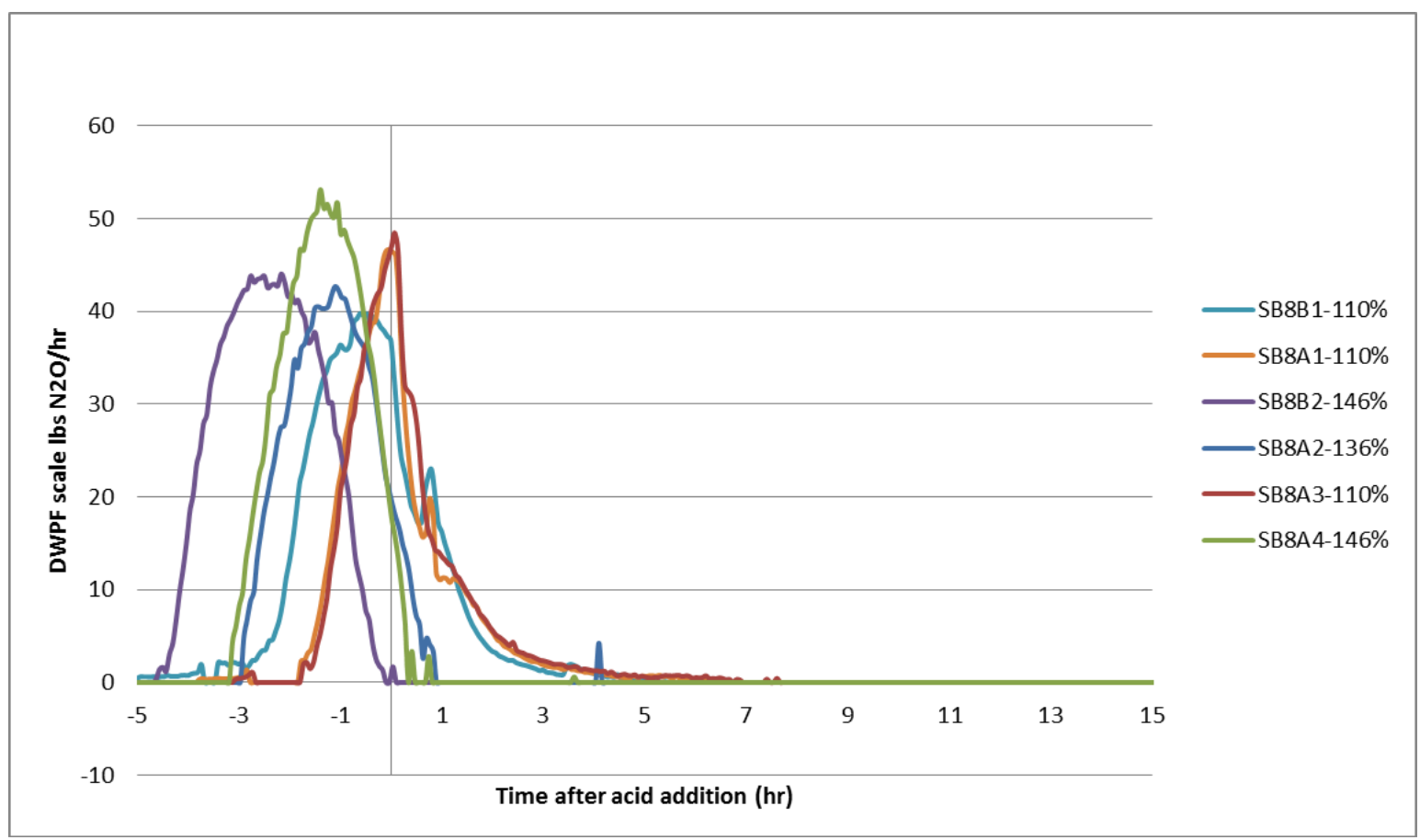

Figure 5. SRAT cycle $\mathrm{N}_{2} \mathrm{O}$ near the end of acid addition

The amount of $\mathrm{N}_{2} \mathrm{O}$ formed was fairly consistent over all the runs, which was a result of nitrite destruction. Numerical $\mathrm{N}_{2} \mathrm{O}$ results are given in Table 12 .

Table 12. SRAT Cycle Nitrous Oxide Generation

\begin{tabular}{|l|c|c|c|c|c|c|}
\hline Run ID: & SB8-A1 & SB8-A3 & SB8-B1 & SB8-A2 & SB8-A4 & SB8-B2 \\
\hline Peak $\mathrm{N}_{2} \mathrm{O}, \mathrm{lb} / \mathrm{h}$ & 46.7 & 48.5 & 39.8 & 42.7 & 53.1 & 44.0 \\
\hline Max vol\% & 2.19 & 2.26 & 2.06 & 2.30 & 2.87 & 2.26 \\
\hline Total $\mathrm{N}_{2} \mathrm{O}, \mathrm{g}$ & 4.45 & 4.47 & 5.90 & 5.04 & 5.97 & 6.34 \\
\hline
\end{tabular}

The three high acid runs appear to have destroyed nitrite around one hour after formic acid addition completed based on the $\mathrm{N}_{2} \mathrm{O}$ data. For the three lower acid runs, nitrite destruction occurred around four hours after formic acid addition. Nitrite destruction coincided with the onset of hydrogen generation, as expected.

\subsection{SRAT Rheology}

Rheological properties of slurries depend on particle size, insoluble solids content, $\mathrm{pH}$, and ionic strength (molarity of ionic charges from cations and anions). For a given insoluble solids matrix, the major factor for SRAT and SME slurries has historically been the wt. \% insoluble solids content. Flow curves were obtained for the six SRAT product slurries. Measurements were made at $25^{\circ} \mathrm{C}$. Previously established flow curve protocols were used ${ }^{13}$. The SRAT results, fit to the Bingham plastic model, are given in Table 13. The rheology results fell below or within the design basis range for yield stress of 1-5 Pa. 
SRNL-STI-2012-00620

Revision 0

Table 13: SRAT Product Slurry Rheology

\begin{tabular}{|l|c|c|}
\hline Run ID: & Yield Stress (Pa) & Consistency (cP) \\
\hline SB8A1-105\% & 1.43 & 7.78 \\
\hline SB8A3-105\% & 3.78 & 6.30 \\
\hline SB8A2-130\% & 0.44 & 5.46 \\
\hline SB8A4-140\% & 0.33 & 5.20 \\
\hline SB8B1-105\% & 0.44 & 4.82 \\
\hline SB8B2-140\% & 0.14 & 3.71 \\
\hline
\end{tabular}

\subsection{SME Cycle}

The six simulant SME cycles are discussed below. Chemical and physical data from process samples will be presented first followed by off-gas data.

\subsubsection{SME Cycle Slurry Samples}

Formate and nitrate loss are presented in Table 14 for samples taken of the SME product slurry. Formic acid was added with the frit-water slurry in all of these runs.

Table 14. SME Anion Reactions

\begin{tabular}{|l|c|c|c|c|c|c|}
\hline Run ID: & SB8-A1 & SB8-A3 & SB8-B1 & SB8-A2 & SB8-A4 & SB8-B2 \\
\hline Formate loss, \% & 13 & 9 & 4 & 9 & -2 & -5 \\
\hline Nitrate loss, \% & 13 & 9 & 5 & 9 & 11 & 4 \\
\hline
\end{tabular}

Formate and nitrate losses between $-10 \%$ and $+10 \%$ cannot be significantly distinguished from zero due to propagated uncertainties in the material balances and analytical results. Anion losses in the SME cycle are typical of previous results ${ }^{12}$.

SME product anion analytical data are given in Table 15 as mg anion/kg slurry.

Table 15. SME Product Anions, mg/kg

\begin{tabular}{|c|c|c|c|c|c|c|}
\hline Anions & SB8-A1 & SB8-A3 & SB8-B1 & SB8-A2 & SB8-A4 & SB8-B2 \\
\hline $\mathrm{NO}_{2}{ }^{-}$ & $<500$ & $<500$ & $<250$ & $<500$ & $<500$ & $<250$ \\
\hline $\mathrm{NO}_{3}{ }^{-}$ & 24,500 & 25,200 & 29,700 & 22,800 & 23,100 & 27,500 \\
\hline $\mathrm{SO}_{4}{ }^{-}$ & 964 & 1,050 & 1,190 & 1,180 & 1,650 & 2,550 \\
\hline $\mathrm{HCO}_{2}{ }^{-}$ & 48,500 & 49,200 & 57,400 & 63,400 & 68,700 & 75,200 \\
\hline $\mathrm{C}_{2} \mathrm{O}_{4}{ }^{-}$ & 2,320 & 2,600 & 2,740 & 2,690 & 4,560 & 3,340 \\
\hline
\end{tabular}

Elemental wt.\% data for the six SME products after calcining at $1100{ }^{\circ} \mathrm{C}$ are given in Table 16 . 
Table 16. SME Calcined Elements at $1100{ }^{\circ} \mathrm{C}-w t . \%$

\begin{tabular}{|c|c|c|c|c|c|c|}
\hline Run ID & SB8-A1 & SB8-A3 & SB8-B1 & SB8-A2 & SB8-A4 & SB8-B2 \\
\hline $\mathrm{Al}$ & 3.00 & 3.07 & 2.49 & 3.02 & 3.01 & 2.59 \\
\hline $\mathrm{B}$ & 1.44 & 1.35 & 1.50 & 1.43 & 1.40 & 1.50 \\
\hline $\mathrm{Ba}$ & 0.052 & 0.044 & 0.038 & 0.044 & 0.042 & 0.037 \\
\hline $\mathrm{Ca}$ & 0.557 & 0.568 & 0.608 & 0.579 & 0.552 & 0.567 \\
\hline $\mathrm{Ce}$ & 0.110 & 0.114 & 0.129 & 0.109 & 0.114 & 0.123 \\
\hline $\mathrm{Cr}$ & 0.082 & 0.083 & 0.336 & 0.079 & 0.080 & 0.310 \\
\hline $\mathrm{Cu}$ & 0.035 & 0.037 & 0.020 & 0.029 & 0.018 & 0.017 \\
\hline $\mathrm{Fe}$ & 7.99 & 8.40 & 8.68 & 8.02 & 8.17 & 8.35 \\
\hline $\mathrm{K}$ & 0.156 & 0.162 & 0.195 & 0.172 & 0.164 & 0.194 \\
\hline $\mathrm{La}$ & 0.025 & 0.026 & 0.022 & 0.026 & 0.031 & 0.021 \\
\hline $\mathrm{Li}$ & 2.17 & 2.11 & 2.26 & 2.18 & 2.20 & 2.29 \\
\hline $\mathrm{Mg}$ & 0.119 & 0.114 & 0.095 & 0.117 & 0.110 & 0.089 \\
\hline $\mathrm{Mn}$ & 2.48 & 2.60 & 3.30 & 2.68 & 2.46 & 2.99 \\
\hline $\mathrm{Na}$ & 10.5 & 10.6 & 10.3 & 10.7 & 10.5 & 10.0 \\
\hline $\mathrm{Ni}$ & 0.569 & 0.574 & 0.364 & 0.530 & 0.534 & 0.357 \\
\hline $\mathrm{Pb}$ & 0.015 & 0.014 & 0.017 & 0.014 & 0.014 & 0.016 \\
\hline $\mathrm{Si}$ & 24.26 & 23.8 & 23.6 & 24.6 & 24.2 & 24.0 \\
\hline $\mathrm{S}$ & 0.122 & 0.131 & 0.111 & 0.117 & 0.119 & 0.082 \\
\hline $\mathrm{Ti}$ & 0.062 & 0.046 & 0.045 & 0.059 & 0.046 & 0.048 \\
\hline $\mathrm{Zn}$ & 0.067 & 0.067 & 0.015 & 0.063 & 0.059 & 0.015 \\
\hline $\mathrm{Zr}$ & 0.166 & 0.137 & 0.139 & 0.161 & 0.140 & 0.141 \\
\hline
\end{tabular}

SME product solids data, densities, and $\mathrm{pH}$ are given in Table 17. SME $\mathrm{pH}$ values are generally lower than those of the SRAT. The lower $\mathrm{pH}$ values are a result of frit added during the SME as a formic acid slurry. The SME targeted $45-49 \mathrm{wt} \%$ total solids. The wt. $\%$ insoluble and soluble solids were calculated from the measured total slurry and supernate (dissolved) solids. The density measurements were made at $25^{\circ} \mathrm{C}$.

Table 17. Additional SME Product Properties

\begin{tabular}{|l|c|c|c|c|c|c|}
\hline Run ID: & SB8-A1 & SB8-A3 & SB8-B1 & SB8-A2 & SB8-A4 & SB8-B2 \\
\hline Wt. \% total solids & 45.78 & 45.05 & 49.25 & 46.89 & 48.98 & 49.27 \\
\hline Wt. \% insoluble solids & 34.99 & 33.40 & 36.19 & 35.66 & 37.31 & 38.25 \\
\hline Wt. \% soluble solids & 10.80 & 11.65 & 13.06 & 11.23 & 11.67 & 11.02 \\
\hline Wt. \% calcined solids & 37.96 & 37.22 & 40.98 & 38.20 & 39.95 & 40.23 \\
\hline Slurry density, g/mL & 1.3931 & 1.3824 & 1.3970 & 1.3572 & 1.4166 & 1.4212 \\
\hline Supernate density, g/mL & 1.1060 & 1.1077 & 1.1329 & 1.1171 & 1.1192 & 1.1221 \\
\hline Product $\mathrm{pH}$ at $25^{\circ} \mathrm{C}$ & 7.38 & 7.36 & 4.97 & 6.06 & 5.61 & 5.17 \\
\hline
\end{tabular}




\subsubsection{SME Off-gas Data}

SME cycle hydrogen generation rates are presented in Figure 6. Frit is added to the SME prior to dewatering. The drop in offgas at around the three hour time is due to the second frit addition.

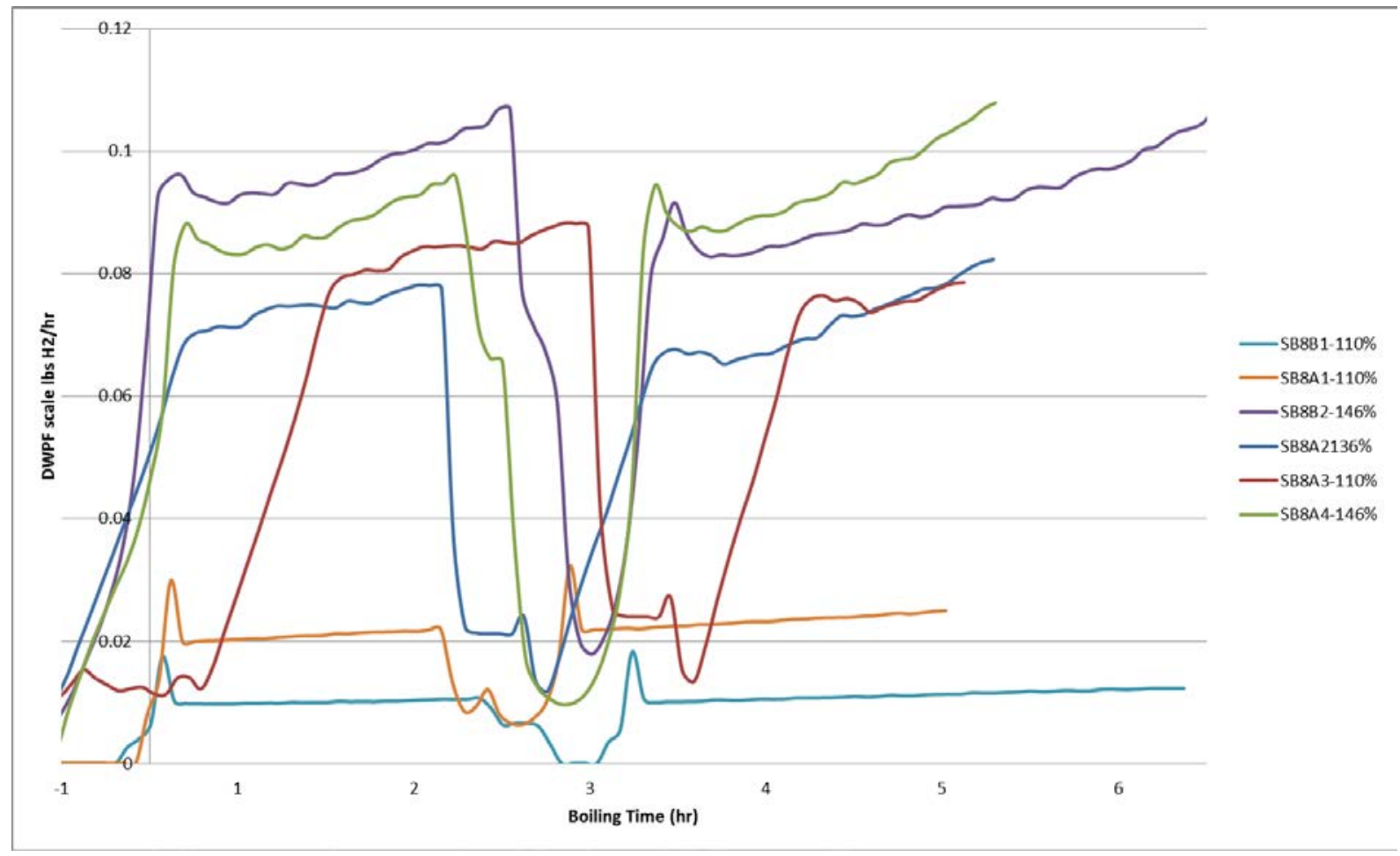

Figure 6. SME Cycle Hydrogen

As the acid stoichiometric factor increased, so did hydrogen generation. None of the six SRAT runs exceeded the DWPF SME hydrogen limit $(0.223 \mathrm{lb} / \mathrm{hr})$. The hydrogen generation rate appears to be increasing prior to termination of the SME cycle. This is a result of concentrating the soluble and insoluble species in the SME slurry. Table 18 presents numerical data for the amounts of hydrogen generated during the SME cycles.

Table 18. SME Cycle Hydrogen Generation

\begin{tabular}{|l|c|c|c|c|c|c|}
\hline Run ID: & SB8-A1 & SB8-A3 & SB8-B1 & SB8-A2 & SB8-A4 & SB8-B2 \\
\hline Peak hydrogen, lb/h & 0.032 & 0.088 & 0.018 & 0.082 & 0.11 & 0.11 \\
\hline \% of SRAT limit & 14 & 40 & 8.0 & 37 & 48 & 49 \\
\hline
\end{tabular}

Carbon dioxide generation rates for the SME cycle are given in Figure 7. The spikes are associated with the onset of boiling following each of the two frit slurry additions. GC data indicated there was no $\mathrm{N}_{2} \mathrm{O}$ generated. 


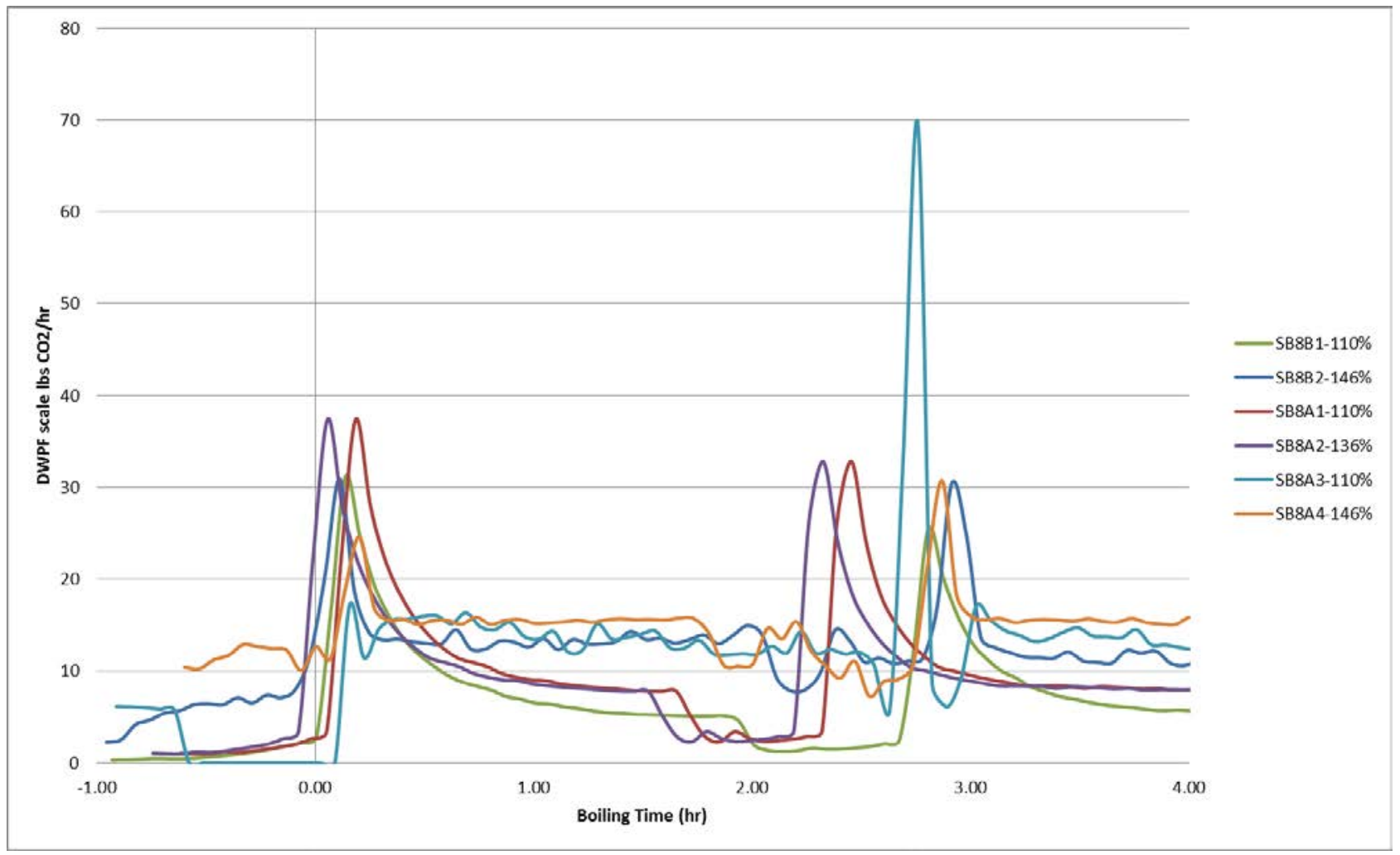

Figure 7. SME Cycle Carbon Dioxide

\subsection{SME Rheology}

Flow curves were obtained for the six SME product slurries. Measurements were made at $25{ }^{\circ} \mathrm{C}$. Previously established flow curve protocols were used ${ }^{14}$. The SME results, fit to the Bingham plastic model, are given in Table 19. Rheology results fall within the SME design basis range of 2.5-15 Pa.

Table 19: SME Product Slurry Rheology

\begin{tabular}{|l|c|c|}
\hline Run ID: & Yield Stress (Pa) & Consistency (cP) \\
\hline SB8A1-105\% & 3.12 & 16.94 \\
\hline SB8A3-105\% & 8.83 & 4.05 \\
\hline SB8A2-130\% & 1.67 & 11.40 \\
\hline SB8A4-140\% & 2.86 & 17.90 \\
\hline SB8B1-105\% & 3.64 & 20.05 \\
\hline SB8B2-140\% & 1.64 & 15.55 \\
\hline
\end{tabular}

\subsection{Conclusions}

SB8 was initially projected to be a combination of the Tank 40 heel (Sludge Batch 7b), Tank 13, Tank 12, and the Tank 51 heel. The wash endpoint target for SB8 was set at a significantly higher sodium concentration to allow acceptable glass compositions at the targeted waste loading.

Four non-coupled tests were conducted using simulant representing Tank 40 at $110-146 \%$ of the Koopman Minimum Acid requirement. Hydrogen was generated during high acid stoichiometry 
(146\% acid) SRAT testing up to 31\% of the DWPF hydrogen limit. SME hydrogen generation reached $48 \%$ of of the DWPF limit for the high acid run.

Two non-coupled tests were conducted using simulant representing Tank 51 at $110-146 \%$ of the Koopman Minimum Acid requirement. Hydrogen was generated during high acid stoichiometry SRAT testing up to $16 \%$ of the DWPF limit. SME hydrogen generation reached $49 \%$ of the DWPF limit for hydrogen in the SME for the high acid run.

Simulant processing was successful using previously established antifoam addition strategy. Foaming during formic acid addition was not observed in any of the runs.

Nitrite was destroyed in all runs and no $\mathrm{N}_{2} \mathrm{O}$ was detected during SME processing.

Mercury behavior was consistent with that seen in previous SRAT runs. Mercury was stripped below the DWPF limit on 0.8 wt $\%$ for all runs.

Rheology yield stress fell within or below the design basis of 1-5 Pa. The low acid Tank 40 run (106\% acid stoichiometry) had the highest yield stress at $3.78 \mathrm{~Pa}$.

\subsection{Acknowledgements}

The author acknowledges the assistance of Jon Duvall, Phyllis Workman, Vickie Williams, David Healy, Beverly Walls, and Doug Sumpter for their support during these around-the-clock runs.

Thank you to Jack Zamecnik for his calibration, operation, and post-run analysis of the FTIR and MS.

Thank you to Frances Williams and John Pareizs for their support of the GC calibration, analysis, and post-run processing.

Thank you to Whitney Riley, Beverly Walls, and David Best for their sample analyses.

Thank you to David Koopman, Mike Stone, Dan Lambert, and Connie Herman for their technical reviews and support. 


\subsection{References}

${ }^{1}$ D.C. Koopman, “DWPF Simulant CPC Studies for SB8,” SRNL-STI-2013-00106, June 2013.

${ }^{2}$ M.E. Stone, “Lab-scale CPC Equipment Setup,” SRNL-L3100-2011-00127, Rev 2, June 2012.

${ }^{3}$ D.C. Koopman, "Noble Metal Chemistry and Hydrogen Generation during Simulated DWPF Melter Feed Preparation,” WSRC-STI-2008-00002, June 2008.

${ }^{4}$ J.D. Newell, “Simulant Development for Sludge Batch 6,” SRNL-STI-2010-00219, April 2010.

${ }^{5}$ C.J. Bannochie, “Tank 40 Final SB7b Chemical Charac terization Results,” SRNL-STI-201200097, March 2012.

${ }^{6}$ M.E. Stone, “Lab-scale CPC Equipment Setup,” SRNL-L3100-2011-00127, July 2011.

${ }^{7}$ D.C. Koopman, A.I. Fernandez, B.R. Pickenheim, "Preliminary Evaluations of Two Proposed Stoichiometric Acid Equations,” SRNL-L3100-2009-00146, 2009.

${ }^{8}$ J.C. Marek, R.E. Eibling, "Calculational Algorithms for Nitric Acid Sludge Adjustment," SRTC-PTD-92-0050, September 1992.

${ }^{9}$ C.M Jantzen, M.E. Stone, "Role of Manganese Reduction/Oxidation (RedOx) on Foaming and Melt Rate in High Level Waste Melters,” WSRC-STI-2006-00066, March 2007.

${ }^{10}$ SRNL L29 Manual, Procedure ITS-0094, Rev. 4, "Laboratory Scale Chemical Process Cell Simulations,” SRNL, Aiken, SC, 29808.

${ }^{11}$ B.J. Wiedenman, T.L. White, R.N. Mahannah, D.R. Best, D.R. Click, M.E. Stone, C.J. Coleman, "Development of Ion Chromatography Methods to Support Testing of the Glycolic Acid Reductant Flowshet in the Defense Waste Proessing Facility,” Draft, SRNL-STI-201300294.

${ }^{12}$ D.C. Koopman, “DWPF Simulant CPC Studies for SB7b,” SRNL-STI-2011-00547, November 2011.

${ }^{13}$ D.C. Koopman, "Rheology Protocols for DWPF Samples,” WSRC-TR-2004-00470, October, 2004. 


\section{Distribution:}

J.W. Amoroso, 999-W

D.R. Best, 999-W

J.M. Bricker, 704-27S

D.R. Click, 999-W

T.B. Edwards, 999-W

T.L. Fellinger, 704-26S

S.D. Fink, 773-A

K.M. Fox, 999-W

J.M. Gillam, 766-H

C.C. Herman, 999-W

E.W. Holtzscheiter, 704-15S

J.F. Iaukea, 704-30S

P.R. Jackson, 703-46A

F.C. Johnson, 999-W

D.C. Koopman, 999-W
D.P. Lambert, 999-W

S.L. Marra, 773-A

J.D. Newell, 999-W

J.E. Occhipinti, 704-S

D.K. Peeler, 999-W

F.M. Pennebaker, 773-42A

H.M. Pittman, 704-27S

J.W. Ray, 704-S

H.B. Shah, 766-H

D.C. Sherburne, 704-S

A.V. Staub, 704-27S

M.E. Stone, 999-W

K.H. Subramanian, 766-H

J.R. Zamecnik, 999-W 